$\begin{array}{ll}\text { Abstracta Iranica } & \begin{array}{l}\text { Abstracta Iranica } \\ \text { Revue bibliographique pour le domaine irano-aryen }\end{array} \\ & \text { Volume } 25 \mid \mathbf{2 0 0 4} \\ \text { Comptes rendus des publications de } \mathbf{2 0 0 2}\end{array}$

\title{
Warfare in Inner Asian History (500-1800). Leyde, Brill, 2002, 456 p.
}

\section{Denise Aigle}

\section{(2) OpenEdition \\ 1 Journals}

\section{Édition électronique}

URL : http://journals.openedition.org/abstractairanica/4479

DOI : 10.4000/abstractairanica.4479

ISSN : 1961-960X

Éditeur :

CNRS (UMR 7528 Mondes iraniens et indiens), Éditions de l'IFRI

\section{Édition imprimée}

Date de publication : 15 mai 2004

ISSN : 0240-8910

\section{Référence électronique}

Denise Aigle, « Warfare in Inner Asian History (500-1800). Leyde, Brill, 2002, 456 p. », Abstracta Iranica [En ligne], Volume 25|2004, document 128, mis en ligne le 15 mars 2006, consulté le 25 septembre 2020. URL : http://journals.openedition.org/abstractairanica/4479; DOI : https://doi.org/10.4000/ abstractairanica. 4479

Ce document a été généré automatiquement le 25 septembre 2020.

Tous droits réservés 


\title{
Warfare in Inner Asian History (500-1800). Leyde, Brill, 2002, 456 p.
}

\author{
Denise Aigle
}

1 Cet ouvrage couvre l'histoire militaire en Asie intérieure sur une vaste période chronologique (500-1800), au cours de laquelle les nomades ont joué un rôle central dans l'histoire de l'Eurasie. Les articles sont répartis en trois périodes chronologiques : "The medieval Period»(500-1200), "The Mongol Age» (1200-1400), et enfin "The Early Modern Period» (1400-1800), centrée essentiellement sur les Qing.

2 L'objectif du livre est de relativiser la thèse, largement admise par la tradition érudite, du topos du « natural warrior » : le trait commun partagé par ces guerriers de la steppe, des Scythes aux Huns et aux Mongols, serait leur habileté militaire. Celle-ci serait le résultat d'un mode de vie spécifique en Asie centrale, qui a vu, avec l'émergence du pastoralisme nomade au $1^{\mathrm{er}}$ millénaire avant J.-C., une situation écologique qui serait restée pratiquement inchangée jusqu'à l'époque moderne. Dans une étude déjà ancienne, mais d'une importance cruciale, D. Sinor [« Horse and Pasture in Inner Asian History ", Oriens Extremus, 19 (1972), pp. 171-184] a démontré que le facteur écologique devait être relativisé : l'endurance légendaire des nomades a une valeur toute relative car elle dépend du terrain et de la nourriture disponibles pour les soldats et les animaux ; par ailleurs, les connaissances techniques du siège de ville, qui étaient bien connues des sédentaires depuis l'Antiquité, faisaient défaut aux nomades. Nous rendrons compte ici des articles qui concernent directement l'histoire du monde iranien médiéval. 
INDEX

Thèmes : 4.1. Histoire médiévale

\section{AUTEURS}

DENISE AIGLE

IFEAD - Damas 